vanishes for large distances, while the second term increases exponentially with increasing distances. The last term contains an eigenvalue $S^{0}$ of the characteristic matrix as factor. Thus, $\psi_{W^{0}}$ will be an eigenfunction corresponding to a closed stationary state only for those real values of $W^{0}<W_{m}^{0}$ which make $S^{0}$ equal to zero.

In this way, the energy values in the closed stationary states are determined as the zero points of the eigenvalues $S^{0}$ of $S$ on the real axis in the $W^{0}$-plane. In the same way, it may be shown ${ }^{4}$ that the singular points of $S^{0}$ in the lower half $W^{0}$-plane determine the energies and decay constants of the system in radioactive states, where the system can emit one of its particles. In fact, these quantities are determined by the real and imaginary parts of those values of $W^{0}$ (in the lower half-plane) where $S^{0}$ has a pole.

It thus seems that all experimental results may be described by means of Heisenberg's characteristic matrix without making use of the wave functions of ordinary quantum mechanics, and it seems possible on these lines to get a relativistic treatment of atomic phenomena, which does not contain the difficulties inherent in all relativistic quantum field theories of the Hamiltonian form.

${ }^{1}$ Heisenberg, W., Report to the Solvay Congress which was planned to take place in 1939.

2Heisenberg, W., “Die 'beobachtbaren' Grössen in der Theorie der Elementarteilchen"', (i) Z. Phys., 120, 513 (1943) ; (ii) ibid., 120 , 673 (1943) ; (iii) and (iv) ibid. (1944-45).

${ }^{3}$ Møller, C., "General Properties of the Characteristic Matrix in the Theory of Elementary Particles, I", D. Kgl. Danske Vidensk. Selsk. Mat.-fys. Medd., No. 1 (1945).

${ }^{4}$ Moller, C., "General Properties of the Characteristic Matrix in the Theory of Elementary Particles, II", D. Kgl. Danske Vidensk. Selsk. Mat.-fys. Medd., No. 19 (1946).

\section{9- HETEROGENESIS AND THE ORIGIN OF VIRUSES}

$\mathrm{T}$

HE name heterogenesignlâs been used to describe the derivation of a limg thing from something unlike itself. In Ifjeyssiohs of this subject many years ago-whether fels could be born of mud, or maggots and hacteria from putrefying matter-it was somepingNilon-living from which organisms were thougbe to have sprung. Later the argument took a dfferent turn and there was speculation as to whether things as small as viruses might not be derived from some constituent of the complex cell-structure of higher animals or plants. This new aspect of the heterogenesis controversy formed the subject of a discussion at the British Association in 1931, opened by Sir Henry Dale, and the matter has now been debated again by the Society for General Microbiology, meeting at Leeds on July 23 .

There are two main conceptions of the origins of viruses. Most workers on animal viruses have maintained that they resemble degraded bacteria which have lost their structural and biochemical complexity in the process of becoming adapted to a specialized parasitism. In the end, in Laidlaw's words, "they live a borrowed life", depending on the host cell for the enzymatic activity necessary for their multiplica. tion.

Alternatively, it is argued, some self-replicating cytoplasmic constituent of a complex cell, such as a plasmagene, may become capable of multiplying when transferred to a new environment such as another cell and acquire an individuality of its own. Such an agent, being complex, would presumably tend to vary; and being variable and self-replicating, would become subject to the laws of natural selection and acquire the status of an independent organism.

All speakers at the discussion agreed that the degraded parasite hypothesis was almost certainly true as regards the animal viruses, at least the larger ones. As Dr. F. M. Burnet of Melbourne pointed out, the student of infectious disease has to assume that view from a pragmatic angle; to the epidemiologist many viruses behave so very much like organisms in general. Dr. G. M. Findlay further noted that occurrences of apparently spontaneous origin of animal viruses were almost unheard of. Quarantine was of undeniable efficiency in keeping out such viruses as rabies, foot-and-mouth disease and rinderpest; these gave no evidence of arising de novo in fresh hosts.

A difficulty arises in regard to the bacteriophages - or as they are coming to be called, bacterial viruses 一 though Dr. A. Felix adduced reasons for refusing to consider them as being viruses at all. The trouble is to imagine, if the degradation hypothesis is applicable, from what the phages could have been degraded. Here Dr. Burnet produced a new and fascinating theory: that they were the direct descendants of precellular stages in the evolution of living forms; after the first bacteria were evolved, such primitive precellular creatures were at a great disadvantage and only those which adopted a parasitic habit within the dominant bacteria were able to survive.

The tailed tadpole-like form which the electron microscope reveals for many bacterial viruses certainly seems to set these apart from other viruses. Indeed, there was a general feeling throughout the discussion that a decision as to the origins of viruses should be taken on their merits for each group, animal, plant and bacterial viruses, and that a tendency for generalization to be too inclusive should be resisted.

The animal pathologists were mainly agreed that the viruses in their field were degraded organisms, but some of them made reservations as regards tumour viruses. Dr. Peyton Rous, whose presence was much welcomed, referred to induction of neoplasms of all sorts in mouse embryo tissue exposed to methylcholanthrene. Could we believe, as seemed to be forced on us by these findings, that a virus was present in all the cells and handed down by heredity ? The tumours produced involved all sorts of tissues and were of most varied histological types. Could each type be due to activation of a different virus? In the case of fowl tumours, the filterable agents were highly specific, each producing a tumour of one precise histological type. The original tumours from which the infective filtrates were derived had no obvious epidemiological connexion with another similar type of tumour. Both Dr. Rous and Dr. A. Haddow leaned to the heterogenetic explanation of the origin of some tumour viruses. But the latter pointed out important distinctions to be drawn among the tumour viruses. That causing rabbit papillomata-from which cancers may derivebehaved like a degraded organism. The Bittner mouse cancer agent also acted like an extrinsic agent but rather less characteristically than did the papilloma virus. The story of the fowl tumour viruses, however, rather suggested the doings of agents of intrinsic origin.

Dr. C. H. Andrewes was reluetant to draw a distinction between tumour viruses and others. $\mathrm{He}$ 
felt that latency and activation by an appropriate stimulus were the characteristic features of the behaviour of many, perhaps most, viruses in their natural hosts. He suggested that with some viruses parasitic adaptation to the host might become so perfect that the individuality of the virus was lost in that of the host cell. This might be permanent; but if the change was a reversible one, viruses brought to light would have an apparently heterogenetic origin. There was some evidence, as in insect viruses and Rickettsiæ, of transmission through the egg.

There was less tendency for speculation among the students of plant viruses, exemplified by Dr. F. C. Bawden. He preferred to "wait and see", but clearly had a weakness for heterogenesis. Virus-like proteins might be normal constituents of some plants, but our present methods of detecting them would not be nearly delicate enough-unless the object of our study was self-reproducing in another environment.

Along with speculation on the origins of viruses must go curiosity as to what they look like. The metal-shadowed electron micrographs which Dr. R. W. G. Wyckoff showed (see Nature of March 2, p. 263) caused much interest and pleasure. The bean mosaic particles, lining up in orderly array to form a crystal, caused a spontaneous burst of applause; while pictures of influenza virus existing as small spheres or, unless our eyes deceived us, as long filaments, left us in awed wonder.

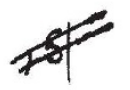

\section{OBITUARIES}

ON June 23, there died at Cone Town, at the age of seventy-four, one to whorplisouth Africa owes much in regar to geological discovery, description and appliffioh. A. W. Wogers was born at Bishops Hull, Somerset, ad. Cducated at Clifton College and Chnivto gollage, Cambridge- of which he was later electedah honorary fellow-and also studied at the Un iversity of Heidelberg. In $1896 \mathrm{he}$ became assistant geologist to the Geological Commission of the Cape of Good Hope, director of the Commission in 1903, and director of the Geological Survey of the Union from 1916 until his retirement in 1932. His thirty-six years of sterling service with the Government were divided equally between the Cape and Transvaal provinces.

Closely associated in the field at first with his colleague, Prof. E. H. L. Schwartz, largely within the picturesque south-western corner of the Cape with its magnificent exposures of folded strata, he was able by 1905 to publish "An Introduction to the Geology of Cape Colony", the first text-book of its kind for southern Africa, and a work of considerable merit. In it were set forth the main tectonic lines, stratigraphy, palæontology and history of this interesting land with its many pre-Cambrian systems, Carboniferous glacials, prolific Permo-Triassic vertebrates and mesozoic dolerites. During the next decade he carried investigation far to the north-- to the border of the Kalahari and German territory-describing little-known pre-Cambrian groups or discovering new ones, such as the crocidolite-bearing jaspers, the Numees tillite, Ongeluk tillite, magmatic copperbearing eruptives and melilite-basalts.

In the Transvaal his main work lay in the mapping of the Heidelberg gold-fields, during which the glacials of the Witwatersrand beds were first recorded.
Administrative duties greatly interfered with his output of purely scientific work. Under his able direction, however, a high standard was achieved by the Geological Survey, and numerous maps and memoirs issued, not a few of them of high economic importance.

Attracted, like so many others, by the vast Kalahari and its queer siliceous and calcareous rocks, he was able to cross its heart as well as inspect its borders, and contributed two illuminating addresses on the solid and surface geology of that sand-strewn region.

Always interested in the finer structure of sub. stances, he developed upon retiring to the Cape in 1932 a still keener interest in the microscopical and microchemical examination of the sedimentary rocks, a study which he pursued the more constantly after 1938, when cardiac disturbances had debarred him from further field work. To many of us such minuter researches proved helpful indeed.

His writings were numerous and varied: for the most part accounts of regional geology appearing as departmental reports or in yearbooks, or else as papers based thereon, though none was of monographic size. His most important works are "The Geology of the Country around Heidellberg", his contribution to the "Handbuch der Regionalen Geologie: The Union of South Africa" (1929) and his fascinating history of "The Pioneers in South African Geology and their Work" (1937), in which so much interesting geological as well as biographical information was so meticulously recorded for posterity. His presidential addresses cover a wider field and range in their subjects from past climates to the evolution of river systems and 'pans'. Only just recently did he complete a description of the Diatom floras of the diatomaceous deposits of the Union in collaboration with L. E. Kent, intended for Memoir No. 42 of the Geological Survey, a research on which he had been long engaged.

In all, Dr. Rogers contributed both abundantly and nobly to our geological and geographical knowledge of a wide terrain, which the writer indeed regards as one of the key regions of the earth.

Connected with many learned societies, he was elected a fellow of the Royal Society of London (1918), the Geological Society of London (1896) and Royal Society of South Africa, as well as honorary fellow, member or correspondent of others. Rogers was president of the Geological Socioty of South Africa (1915), of the South African Association for the Advancement of Science (1922), of the International Geological Congress (1929) and of the Royal Society of South Africa (1934-35).

His awards were numerous: the Bigsby Medal (1907) and Wollaston Medal (1931) of the Geological Society; South Africa Medal (1913) of the South African Association for the Advancement of Science; Scott Medal (1931) of the Biological Society of South Africa, and Draper Memorial Medal (1936) of the Geological Society of South Africa.

Rogers will always be remembered for his geniality, readiness to discuss or guide, scrupulous attitude towards the work or views of others, and honesty of purpose. His outlook was, however, coloured by some conservatism. Throughout, he was the sqientific worker pursuing his subject for its own sake, and perhaps for that reason the grander problems of the African continent do not seem to have gripped him. Having been closely associated with Arthur Rogers over many years, the writer feels that a noteworthy geologist has been lost to the world.

Alex. L. DE TOIT 